\title{
Development of noodles with low cost Silver carp fish (Hypophthalmichthys molitrix) mince
}

\author{
FATEMA HOQUE SHIKHA, MD. ISMAIL HOSSAIN* AND LABIBA FARZANA \\ Department of Fisheries Technology, \\ Bangladesh Agricultural University, Mymensingh 2202, Bangladesh \\ *Email: ihossain.ft@bau.edu.bd
}

\begin{abstract}
The study was conducted to prepare fish noodles using silver carp (Hypophthalmichthys molitrix) mince with wheat flour and to assess it's cooking quality. The silver carp muscle was first boiled for 10-12 minutes and then skin and bones were separated to prepare mince. Silver carp fish mince was incorporated with wheat flour and other ingredients in the substitution levels of $0,20,25$ and $30 \%$. The noodles were prepared using a homestead noodle maker. The noodles samples with the increasing levels of silver carp mince in the formulations had increased ash, protein, fat and calories but the moisture content and total carbohydrate decreased with the increase of fish mince substitution level. The noodles with $30 \%$ silver carp mince had highest level of moisture content and had higher levels of protein, fat and calories (per $100 \mathrm{~g}$ ) compared to 0,20 and $25 \%$ silver carp mince in the noodle formulation. The noodles prepared with $20 \%$ silver carp mince had the lowest level of protein, fat and calories among three levels of mince substitutions. The cooking time of noodles with silver carp mince was lower than that of control one. For control sample the cooking time required was 3 minutes where as for the other 3 samples required cooking time was 2 minutes. The prepared noodles had higher level of water absorption capacity and increased the weight of the cooked noodles with the increasing amount of silver carp mince in the noodles The result of the study indicated that- the incorporation of fish muscle with popular snack item like noodles might contribute to the health benefit for the consumers.
\end{abstract}

Key words: Silver carp, Fish noodles, Fish mince, Cooking quality

\section{Introduction}

Noodles are a type of food made from unleavened dough which is rolled flat and cut, stretched or extruded, into long strips or strings. Noodles are a staple food in many cultures (Wikipedia). According to Oxford Dictinary, the word was derived in the 18th century from the German word Nudel. Roach (2005) stated that- the earliest written record of noodles in China is found in a book dated to the Eastern Han period (25-220 CE). It became a staple food for the people of the Han dynasty (Sinclair and Sinclair 2010). Noodles are accepted by people from all over the world. The industrial revolution and the development of the food industry realized the transition from a traditional handicraft industry to mass production using machinery. In addition, the invention of instant noodles and their mass production also greatly changed the noodle industry. In essence, noodles are a kind of cereal food, which is the main body of the traditional Chinese diet. It is the main source of energy for Chinese people and the most economical energy food. Adhering to the principle of "making cereal food the main food", is to maintain Chinese good diet tradition, which can avoid the disadvantages of a high energy, high fat, and low carbohydrate diet, and promote health (Zhang and Ma 2016). Generally the noodles available in the market are made of wheat flour, egg, oil, salt and some other extra added flavor in some special case. These noodles are highly rich in carbohydrate but poor in protein content. Kumar et al. (2011) reported that, wheat provides nearly $55 \%$ of carbohydrate and $20 \%$ of the food calories. It contains carbohydrate $78.10 \%$, protein $14.70 \%$, fat $2.10 \%$, minerals $2.10 \%$. The 
people of Bangladesh have a wide and rich source of carbohydrate as rice is the staple food. Rice and wheat account for $62 \%$ and $54 \%$ of total intake of all foods per capita per day for rural and urban people respectively (Humaywn 1995). In terms of nutritionally intake rice and wheat constitute about $84 \%$ of total calorie consumption intake per capita per day (BBS 1986). But their lacking often causes due to scarcity of protein and fat in the diet. Considering this point, an idea has been generated to increase the amount of protein and fat content of noodles in a cheaper way by incorporating fish muscle protein with wheat flour.

Silver carp is the most common, popular and cheapest fish species in Bangladesh (though intramuscular bones are comparatively higher in this species but these bones could be removed during fish mince preparation). Therefore, silver carp may be chosen as fish protein source to develop nutritious fish noodles. If silver carp fish muscle is added to noodles then all the nutrients present in fish muscle might be absorbed in a tasty and easy way of consumption. Various types of value-added products are prepared from fish such as frozen block, frozen fingers, steaks, fillets, fish stick, fish ball etc. which are quite common. The most important item among the group of value added products is the battered and breaded products or coated products processed out of a variety of fish and shellfish (Viji et al. 2018). But preparing noodles using silver carp mince seems a unique idea. So far in Bangladesh literatures on the development of noodles from silver carp (Hypophthalmichthys molitrix) and related study is scare. Considering above mentioned facts, the present study was conducted to develop protein enriched noodles incorporating silver carp $(H$. militrix) fish muscle with wheat flour (bigger source of carbohydrate) and other ingredients at different levels of muscle inclusion. At the same time cooking quality of the prepared fish noodles was also carried out.

\section{Materials and Methods}

Silver carp fish, wheat flour and other major ingredients (salt, oil, and different spices) were procured from K,R market, Bangladesh Agricultural University campus. The noodles were made with the help of a vertical noodle maker.

Preparation of silver carp mince: Fresh fish samples were cut by discarding the head, fins, tail, and viscera and then washed with clean water. Then the fish (only flashy parts of fish) was boiled with clean water for few minutes (10-12 minutes). After boiling the soft flesh pieces were deboned manually. Oil and skin were also separated from the fleshes. The fleshes were minced manually (as noodles was prepared in a homestead manner) with hand (Plate I). The fish mince was packed in a plastic container and stored in a refrigerator until further use.

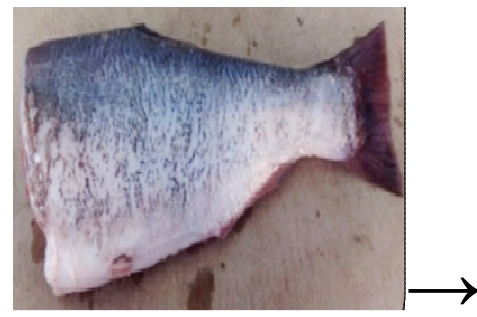

Washed silver carp

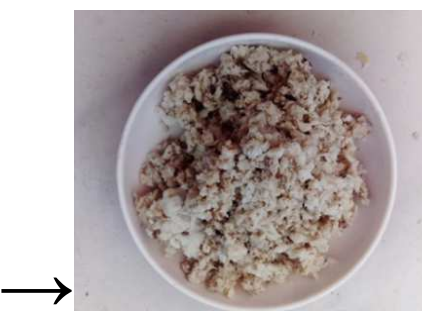

Silver carp mince ate I: Preparation of fish mince

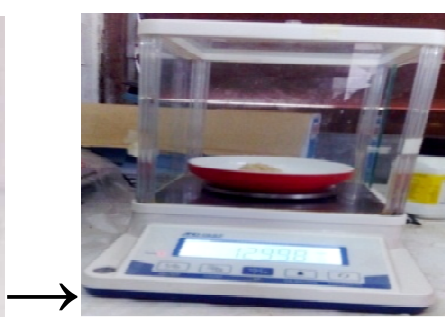

Weighing of the mince 
DEVELOPMENT OF NOODLES WITH SILVER CARP FISH MINCE

Table I. Basic formulation of $100 \mathrm{~g}$ noodles with wheat flour and silver carp mince

\begin{tabular}{l|c|c|c|c}
\hline \multirow{2}{*}{ Ingredients } & \multicolumn{4}{|c}{ Samples } \\
\cline { 2 - 5 } & $\mathrm{C}$ & $\mathrm{S} 1$ & $\mathrm{~S} 2$ & $\mathrm{~S} 3$ \\
\hline Wheat flour (g) & 100 & 80 & 75 & 70 \\
Silver carp mince (g) & 0 & 20 & 25 & 30 \\
Water (ml) & 40 & 40 & 40 & 40 \\
Oil (ml) & 5 & 5 & 5 & 5 \\
Salt (g) & 2 & 2 & 2 & 2 \\
Spices (g) & 0.5 & 0.5 & 0.5 & 0.5 \\
\hline
\end{tabular}

${ }^{*} \mathrm{C}=$ control noodles with wheat flour only; $\mathrm{S} 1=$ noodles with $80 \%$ wheat flour, $20 \%$ silver carp mince; $\mathrm{S} 2=$ noodles with $75 \%$ wheat flour, $25 \%$ silver carp mince; $\mathrm{S} 3=$ noodles with $70 \%$ wheat flour, $30 \%$ silver carp mince.

Formulation and preparation of noodles: The formulation of fish noodles is presented in Table I. The wheat flour was replaced with $0,20,25$ and $30 \%$ of silver carp mince in the formulation C (control-noodles without fish mince), S1 (noodles prepared with $20 \%$ fish mince),S2 (noodles prepared with $25 \%$ fish mince), S3 (noodles prepared with $30 \%$ fish mince), respectively. All the ingredients such as wheat flour, silver carp mince, salt, oil and spices were weighed as shown in Table I. The ingredients were mixed with warm water (water temperature was around 35 to $40^{\circ} \mathrm{C}$ ) and kneaded for 10 minute to prepare dough. The dough was transferred to a vertical noodles making machine and longer types of noodles were made. The prepared noodles were then sun-dried for 2 days. The cooled and dried noodles were kept in polythene packs until further use (Plate II).

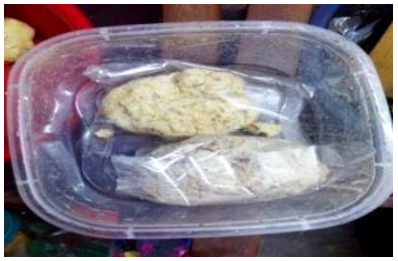

A

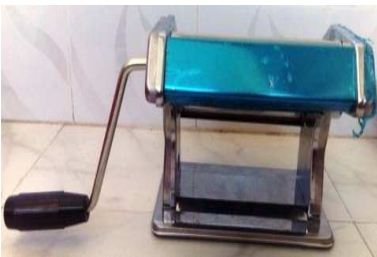

B

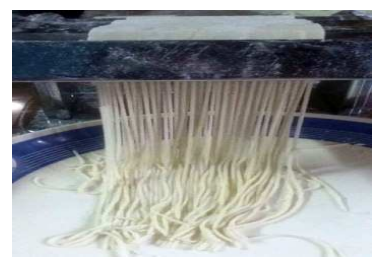

$\mathrm{C}$

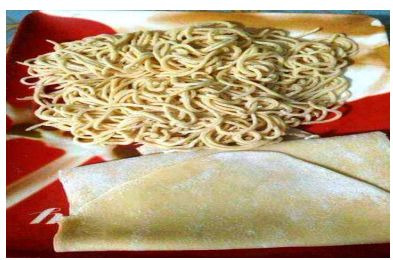

$\mathrm{D}$

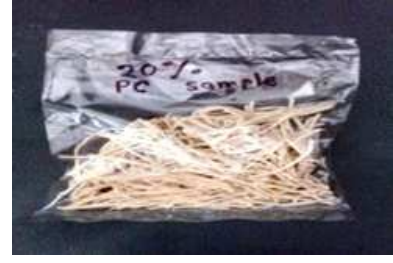

E

Plate II. Preparation procedure of noodles

(A: Preserved mince in plastic box for noodle making; B: Vertical noodle maker; C: Making of noodles;

D: Raw noodles; E:Sealer; F: noodle in sealed pack)

Chemical analysis: The wheat flour, silver carp mince and the prepared noodles were analyzed for moisture, protein, ash, fat by AOAC (2004) and AOAC (2000) method. The total carbohydrates were calculated by approximation i.e. indirectly, by subtracting the measured protein, moisture, fat, and ash from 100 (Srivastava and Sanjeev 2002).Total calorie of the samples was calculated using the following formula (as Srivastava and Sanjeev 2002): 
Calorie of the samples was

Calorie $=[9 *(\mathrm{~g}$ fat $)]+4 *(\mathrm{~g}$ protein $)+4 *(\mathrm{~g}$ carbohydrate $)$

Cooking of noodles: Hundred grams noodles were cut into $4 \mathrm{~cm}$ length and were added to a beaker containing about $225 \mathrm{ml}$ of boiling distilled water on a hot plate and was cooked at $100^{\circ} \mathrm{C}$ for $2-3$ minutes and stirred slightly with a glass rod. The noodles were cooked and the samples were weighed. The difference in weight between the boiled sample and the dry sample is water absorption during cooking.

\section{Results}

Proximate composition of silver carp fish, silver carp mince and wheat flour: The Proximate composition of silver carp fish, silver carp mince and wheat flour is given in Table II. The moisture contents were found $77.71 \%, 75,79 \%$ and $12.91 \%$ in silver carp fish, silver carp mince and wheat flour, respectively. The protein content obtained highest in silver carp mince $(20.60 \%)$ and lowest $(13.31 \%)$ in wheat flour. In case of fat content the difference was minimum among silver carp fish $(1.33 \%)$ and silver carp mince $(1.68 \%)$ where the lowest value $(0.85 \%)$ was found for wheat flour. Though the value of ash content was found highest $(1.18 \%)$ in silver carp fish but the highest value $(72.40 \%)$ for total carbohydrate was obtained for wheat flour.

Table II. Proximate composition of silver carp fish, silver carp mince and wheat flour

\begin{tabular}{l|c|c|c}
\hline Components & Silver carp fish & Silver carp mince & Wheat flour \\
\hline Moisture (\%) & 77.71 & 75.97 & 12.91 \\
Protein (\%) & 18.02 & 20.60 & 13.31 \\
Fat $(\%)$ & 1.33 & 1.68 & 0.85 \\
Ash (\%) & 1.18 & 1.40 & 0.53 \\
Total carbohydrate & & & \\
(\% by difference) & 1.76 & 0.35 & 72.4 \\
\hline
\end{tabular}

Proximate composition of prepared noodles: The four different samples of noodles were analyzed for moisture, ash, protein, fat, total carbohydrate, calories and the results are presented in Table III. The moisture content of the different noodles samples prepared with different levels of wheat flour and silver carp mince ranged from 6.37 to11.94\%. The lowest value was found for sample $\mathrm{C}$ and the highest value was for sample S3 (Table 3). Protein content (\%) of different samples were obtained (Table III) 10.50 for sample C, 19.35 for sample S1, 22.33 for sample S2 and 23.66 for sample S3. The lipid content of the prepared noodles ranged from 3.68 to 6.15 where for percent ash content the range is within 1.49 to 3.00. The highest total carbohydrate content was found $74.19 \%$ in sample $\mathrm{C}$ (control sample) and the lowest value $56.42 \%$ in sample S3. It was also observed that the carbohydrate content decreased with increasing amount of silver carp mince. On the other hand the lowest value in calorie (per $100 \mathrm{~g}$ ) was obtained 365.15 for sample S3 and the highest value 394.11 for sample C (Table III). 
DEVELOPMENT OF NOODLES WITH SILVER CARP FISH MINCE

Cooking quality of noodles: The four different samples of noodles were analyzed for the cooking quality (weight of $100 \mathrm{~g}$ of dried noodles, cooking time, water absorption etc.) and the results are presented in Table IV.

Table III. Proximate composition of prepared noodles

\begin{tabular}{l|c|c|c|c|c|c}
\hline Sample* & $\begin{array}{c}\text { Moisture } \\
(\%)\end{array}$ & $\begin{array}{c}\text { Lipid } \\
(\%)\end{array}$ & $\begin{array}{c}\text { Protein } \\
(\%)\end{array}$ & $\begin{array}{c}\text { Ash } \\
(\%)\end{array}$ & $\begin{array}{c}\text { Total carbohydrate } \\
(\%)\end{array}$ & $\begin{array}{c}\text { Calories } \\
\text { (per 100 g) }\end{array}$ \\
\hline $\mathrm{C}$ & 6.37 & 6.15 & 10.50 & 2.53 & 74.19 & 394.11 \\
\hline $\mathrm{S} 1$ & 9.91 & 3.68 & 19.35 & 1.49 & 65.57 & 372.80 \\
\hline S2 & 10.92 & 4.86 & 22.33 & 1.78 & 60.11 & 373.5 \\
\hline S3 & 11.94 & 4.98 & 23.66 & 3.00 & 56.42 & 365.14 \\
\hline
\end{tabular}

Table IV. Cooking quality test of prepared noodles

\begin{tabular}{l|c|c|c|c}
\hline Samples* & $\begin{array}{c}\text { Cooking time } \\
\text { (min) needed }\end{array}$ & $\begin{array}{c}\text { Weight of the dry } \\
\text { noodles }(\mathrm{g})\end{array}$ & $\begin{array}{c}\text { Weight of the wet } \\
\text { noodles }(\mathrm{g})\end{array}$ & $\begin{array}{c}\text { Water absorption } \\
(\%)\end{array}$ \\
\hline $\mathrm{C}$ & 3 & 100 & 212 & 112 \\
\hline $\mathrm{S} 1$ & 2 & 100 & 224 & 124 \\
\hline $\mathrm{S} 2$ & 2 & 100 & 232 & 132 \\
\hline $\mathrm{S} 3$ & 2 & 100 & 245 & 145 \\
\hline \multirow{2}{*}{$\mathrm{C}=$ Control noodles with wheat flour; S1 $=80 \%$ wheat flour, $20 \%$ silver carp mince; S2=75\% wheat flour, } \\
\multicolumn{2}{l}{ 25\% silver carp mince; S3=70\% wheat flour, 30\% silver carp mince. }
\end{tabular}

As shown in Table IV, the lowest cooking time was $2 \mathrm{~min}$ for the sample S1, S2, S3. The cooking time required for sample $\mathrm{C}$ was $3 \mathrm{~min}$. The highest water absorption (\%) value of the prepared noodles was $145 \%$ for the sample S3. The other values of water absorption (\%) for sample S2 was $132 \%, 124 \%$ for S1 and $112 \%$ for C. The lowest water absorption value was obtained for $\mathrm{C}$ (control sample) indicating the degradation level of starch as $\mathrm{C}>\mathrm{S} 1>\mathrm{S} 2>\mathrm{S} 3$.

\section{Discussion}

Proximate composition of silver carp fish, silver carp mince and wheat flour: Ashraf et al. (2011) reported percent moisture content 74.56 for grass carp and 78.33 for silver carp in a study carried out on the nutritional values of wild and cultivated fishes of these two species. Asgharzadeh et al. (2010) found $78.6 \%$ moisture in silver carp (H. molitrix) minced muscle in a study on the chemical changes in minced muscle during frozen storage. These results are quite similar to the obtained values in the present study. Protein content $16.5 \%$ and lipid content $2.27 \%$ were reported for silver carp minced muscle (washed) by Asgharzadeh et al. (2010). Hakimeh et al (2010) reported that steamed Silver carp (H. molitrix) fillets contain $75.77 \%$ moisture, $18.92 \%$ protein, $1.55 \%$ fat and $1.20 \%$ ash. Devadsan et al. (1978) found in his experiment lower amount of ash content in six freshwater fishes Labeorohita (1.31\%), Catla catla (0.93\%), Cirrihinus cirrhosus (1.40\%), Labeo calabasu (1.02\%), Mystus seeghala $(0.91 \%)$ and Wallagu attu $(0.72 \%)$. All these results are quite similar to the findings of present study. Wheat flour contained moisture $12.91 \%$, protein 13.31 , fat $0.85 \%$, ash $0.53 \%$ and total carbohydrate (by difference) $72.4 \%$ (Table II). Ocheme et al. (2018) reported $9.1 \%$ moisture 
content, protein content $14.70 \%$, fat content $1.93 \%$, carbohydrate $72.73 \%$, and ash content $0.70 \%$ for wheat flour and crude fiber $0.84 \%$. Kulkarni et al. (2012) also reported that the wheat flour contains moisture $12.67 \%$, protein $10.55 \%$, fat $0.94 \%$, ash $0.94 \%$, total carbohydrate $74.88 \%$ and crude fibre $0.36 \%$. These reported values are more or less in agreement with the obtained values in the present study.

Proximate composition of prepared noodles: Hakoda et. al. (2006) determined the moisture content of instant noodles. They reported, after removal of outliers statistically, the repeatability (RSDr) and the reproducibility [ $(\mathrm{RSD}(\mathrm{R})]$ of the methods were $1.6-2.6$ and $3.9-4.8 \%$ for fried noodles, and 0.3-1.5 and 1.3-2.9\% for non-fried noodles, respectively. The values found in this study are more or less near to these range. The little difference might be observed due to the variation in drying temperature and duration of drying. Ejembi et. al. (2014) reported that the protein content of his prepared noodles was $12.69 \%$ which is very much lower than the protein contents of samples S1, S2 and S3 but a little bit higher than the value obtained for control sample. This is might be due to the substitution of wheat flour with silver carp mince which is a good source of protein itself. Mishra and Bhatt (2016) reported $1.14 \%$ fat content in pasta. In the present study, the fat content ranged from 3.68 to $6.25 \%$ which is little higher than previous report and this is might be contributed to the noodles as $5 \mathrm{ml}$ soybean oil was used during noodles preparation and also the presence of silver carp muscle in different inclusion levels. Ash content increased with increasing level of silver carp mince in the prepared noodles. Mishra and Bhatt (2016) found $3.32 \%$ ash content in their experimental pasta which is quite similar to the values of ash content obtained in the present study indicating that the noodles of this study had significantly higher levels of minerals. In the same study they also observed the carbohydrate content $73 \%$ which is closer to values of the present study.

Cooking quality of noodles: Park and Baik (2004) reported the cooking time of white salted noodles and its relationship with protein and amylose contents of wheat. Optimum cooking time of white salted noodles determined by sensory panel test ranged from 13.6-16.2 minutes in wheat of wild type in granule bound starch synthase (GBSS), from 16-17.4 minutes in B null in GBSS, from 11.4-12.4 minutes in commercial noodle flours, from 8.0-8.2 minutes in waxy wheat, and 14.2 minutes in BD double null. Both protein and starch amylase content of wheat significantly influenced water absorption for making noodles and cooking time of white salted noodles. Optimum cooking time of noodles increased as protein content of flour increased, except in waxy wheat flours. Waxy wheat flours, despite their high protein content $(>17.1 \%)$, exhibited the shortest cooking time of noodles, signifying the influence of starch amylase content on cooking time of noodles. Estimated cooking time based on the changes in amylograph onset temperature of noodles during cooking well matched with optimum cooking time as determined by sensory panel test, with a standard error of estimation of 1.23. Kang et al. (2017) studied the physicochemical and textural properties of noodles prepared from different potato varieties (Atlantic, Go-un, Sae-bong, Jin-sun) with wheat flour. They reported percent water absorption, 122.83, 75.70, 80.73, 92.82 and 83.02; percent cooking loss 4.12, 6.35, 6.51, 6.42 and 6.45; volume increase $175.86,103.45,113.79,139.66$ and 122.41 respectively, for the noodle samples of above said compositions. Sirichokworrakit (2014) carried out a research on physical, textural and sensory properties of noodles supplemented with tilapia bone flour (addition of 5, $10,15 \%$ flour by weight). In his experiment he observed, water absorption (\%)104.25, 95.74, $92.35,89.85$; cooking time (sec.) 115, 110, 110, 120; cooking loss (\%) 2.95, 3.11, 3.23, 3.31, respectively for the experimental samples. The results obtained in the present study are more or 
less in agreement with the previous studies described above indicating that decrease in carbohydrate content contribute lesser time for cooking and increase the percent water absorption in noodles.

\section{Conclusions}

The study could be concluded that, the increasing levels of silver carp mince in the formulations of noodles contribute in the increase of ash, protein, fat and calories in noodle samples but the moisture content and total carbohydrate decrease. The cooking time of noodles with silver carp mince was lower than that of control one but the water absorption capacity found higher with the increasing amount of silver carp mince in the noodles. Incorporation of fish protein with popular carbohydrate based snacks like noodles may contribute to the health benefit for the consumers.

Acknowledgement: This research was funded by Bangladesh Agricultural University Research System.

\section{Literature Cited}

Ackman, R., 1989: Fatty Acids. In: Marine Biogenic Lipids, Fats and Oils (ed. R. Ackman), CRC Press, Boca Raton, Florida. 103-137.

AOAC (Association of Official Analytical Chemists), 2000. Official methods of analysis. 17th edition. Association of Official Analytical Chemists. Washington DC.

AOAC (Association of Official Analytical Chemists), 2004. Official methods of analysis. 17th edition.Association of Official Analytical Chemists. Washington DC.

Asgharzadeh, A., B. Shabanpour, S.P. Aubourg and H. Hossein, 2010. Chemical changes in silver carp (Hypophthalmichthys molitrix) minced muscleduring frozen storage: Effect of a previous washing process. GRASAS Y ACEITES 61 (1): 95-101

Ashraf, M., A. Zafar, A. Rauf, S. Mehboob and N.A. Qureshi, 2011. Nutritional values of wild and cultivated silver carp (Hypophthalmichthys molitrix) and grass carp (Ctenopharyngodon idella). Int. J. Agric. Biol., 13: 210-214.

BBS, 1986. Report of the Bangladesh Household Expenditure Survey. Ministry of Planning, Government of the People's Republic of Bangladesh, Dhaka.

Devadasan, K., P.R.G. Varma and R. Venkataraman, 1978. Studies on frozen storage characteristics of fillets from six species of fresh water fish. Fish. Technol.,15: 1-6.

Ejembi, D., M. Sanni, F.T. Emmanuel and O.C. Abbah, 2014. Evaluation of the biochemical composition and proximate analysis of indomie noodle. Int. J. Med. Appl. Sci., 3(1): 1014.

Hakimeh, J.A., A.A. Akram, S. Bahareh and S.M. Alireza, 2010. Physicochemical and sensory properties of silver carp (Hypophthalmichthys molitrix) fillets as affected by cooking methods. Int. Food Res. J., 17: 921-926.

Hakoda, A., H. Kasama, K. Sakaida, T. Suzuki and A. Yasui, 2006. Determination of the moisture content of instant noodles: Inter-laboratory study. J AOAC Int., 89(6): 1585-90.

Humaywn, M.K., 1995. A study on consumption pattern of some selected commodities in sadar thana of Mymensingh district. MS thesis, Department of Cooperation and Marketing, Bangladesh Agricultural University, Mymensingh-2202, Bangladesh.

Kang, J., J. Lee, M. Choi, Y. Jin, D. Chang, Y.H. Chang, M. Kim, Y. Jeong and Y. Lee, 2017. Physicochemical and textural properties of noodles prepared from different potato varieties. Prev. Nutr. Food Sci., 22(3): 246-250. 
Kulkarni, S.S., A.D. Desai, R.C. Ranveer and A.K. Sahoo, 2012. Development of nutrient rich noodles by supplementation with malted ragi flour. Int. Food Res. J., 19(1): 309-313.

Kumar, O., R.K. Yadava, B. Gollen, S. Kumar, R.K. Verma and S. Yadav, 2011. Nutritional contents and medicinal properties of wheat: A review. Life Sci. Med. Res., 2011: LSMR-22 Manual on Value Addition of Seafood, 19-24.

Mishra, P. and D.K. Bhatt, 2016. A Study on development of fortified pasta with ginger powder. J. Env. Sci. Toxicol. Food Tech., 10(8): 14-18.

Ocheme, O.B., O.E. Adedeji, C.E. Chinma, C.M. Yakubu and U.H. Ajibo, 2018. Proximate composition, functional and pasting properties of wheat and groundnut protein concentrate flour blends. Food Sci. Nutr., 6(5): 1173-1178.

Park, C.S. and B.K. Bike, 2004. Cooking time of white salted noodles and its relationship with protein and amylose contents of wheat. Cereals and Grains Association. 81(2): 165-171.

Roach, J., 2005. "4,000-Year-Old Noodles Found in China". National Geographic. Sinclair \& Sinclair 2010, $91 \mathrm{p}$.

Sirichokworrakit, S., 2014. Physical, textural and sensory properties of noodles supplemented with tilapia bone flour (Tilapia nilotica). Int. J Agril.Biosys. Eng, , 8 (7): 745-747.

Srivastava, R.P. and S. Kumar, 2002. Fruit and vegetable preservation: Principles and practices 3rd Revised and Enlarged edn. Published by BIO-GREEN Books.

Zhang, N. and G. Ma, 2016. Noodles, traditionally and today. J. Ethn Food., 3 (3): 209-221.

(Manuscript received 12 May 2020) 